\title{
Experimental analysis of a flat plate solar collector with integrated latent heat thermal storage
}

\author{
* Mauricio, Carmona ${ }^{1}$, Mario Palacio ${ }^{2}$, Arnold Martínez ${ }^{3}$ \\ 1 Mechanical Engineering Department, Universidad del Norte, Colombia \\ 2 Faculty of Mechanical and Industrial Engineering, Universidad Pontificia Bolivariana, Colombia \\ ${ }_{3}$ Mechanical Engineering Department, Universidad de Córdoba, Colombia \\ 'E mail: mycarmona@uninorte.edu.co , 2E mail: mario.palaciov@upb.edu.co
}

\begin{tabular}{|l|}
\hline A R T I C L E I N F O: \\
\hline Article history: \\
Received 2 August 2017 \\
Accepted 10 August 2017 \\
Available online 12 October \\
2017 \\
\hline Keywords: \\
Solar collector; \\
Thermal storage; \\
Latent heat storage.
\end{tabular}

This work is licensed under a Creative Commons Attribution NonCommercial - NoDerivs 4.0. "CC-BY-NC-ND"

\begin{abstract}
A B S T R A C T
In the present paper, an experimental analysis of a solar water heating collector with an integrated latent heat storage unit is presented. With the purpose to determine the performance of a device on a lab scale, but with commercial features, a flat plate solar collector with phase change material (PCM) containers under the absorber plate was constructed and tested. PCM used was a commercial semi-refined light paraffin with a melting point of $60^{\circ} \mathrm{C}$. Tests were carried out in outdoor conditions from October 2016 to March 2017 starting at 7:00 AM until the collector does not transfer heat to the water after sunset. Performance variables as water inlet temperature, outlet temperature, mass flow and solar radiation were measured in order to determine a useful heat and the collector efficiency. Furthermore, operating temperatures of the glass cover, air gap, absorber plate, and PCM containers are presented. Other external variables as ambient temperature, humidity and wind speed were measured with a weather station located next to the collector. The developed prototype reached an average thermal efficiency of $24.11 \%$ and a maximum outlet temperature of $50^{\circ} \mathrm{C}$. Results indicate that the absorber plate reached the PCM melting point in few cases, this suggests that the use of a PCM with a lower melting point could be a potential strategy to increase thermal storage. A thermal analysis and conclusions of the device performance are discussed.

JOURNAL OF CONTEMPORARY URBAN AFFAIRS (2017) 1(3), 7-12.

https://doi.org/10.25034/ijcua.2018.36zd72
\end{abstract}

www.ijcua.com

Copyright (C) 2017 Journal Of Contemporary Urban Affairs. All rights reserved.

\section{Introduction}

Solar energy is the most widely available energy source in the world. However, it presents some obstacles to its implementation such as sensitivity to climatic conditions and intermittency. Therefore, it is necessary to develop technologies that allow storing solar energy for the periods in which it is not available, or its power is low. Two common methods of storing solar thermal energy are sensible and latent heat storage. While sensible heat is more common in practical applications, latent heat storage provides higher storage density, with narrow temperature variation. (Abhat, 1983) reported one of the earliest reviews on latent heat thermal storage. (Zalba et al., 2003) reviewed thermal

\footnotetext{
*Corresponding Author:

Mechanical Engineering Department, Universidad del Norte, Colombia

E-mail address: mycarmona@uninorte.edu.co
} 
energy storage with PCM and its heat transfer analysis and applications. (Farid et al., 2004; Kenisarin and Mahkamov, 2007; Nkwetta and Haghighat, 2014; Sharma et al., 2009) reviewed solar energy storage using phase change materials. (Chandel and Agarwal, 2017) Reviewed the current state of research on energy storage, toxicity, health hazards and commercialization of phase changing materials. (Pandey and Chaurasiya, 2017) reviewed the analysis and development of solar flat plate collectors.

Although numerous works on latent heat storage, no commercial solar heaters with builtin PCM storage have been reported. However, preliminary studies in laboratory prototypes have shown considerable increases in efficiency and supply capacity. (Kürklü et al., 2002) found a large difference between ambient temperature and water temperature both at day and at night. With the experimental techniques used, it was not possible to determine the phase change point at least in a general approach. No performance comparison is made against traditional devices. However they showed that its prototype has advantages in manufacturing cost and total weight for commercial devices, although it does not include an energy analysis. In countries with tropical climates, no scientific references have been found in studies of this kind of technology, in spite of the great capacity of available solar energy, quite possibly due to the lack of suitable commercial PCMs for this application. (Mehling et al., 2003) presented experimental results and numerical simulation of a water tank with a PCM module using an explicit finite-difference method. Experiments and simulations indicated an increase in energy density of the tank of $20 \%$ to $45 \%$. (Canbazoglu et al., 2005) Analyzed experimentally the time variations of the water temperatures at the midpoint of the heat storage tank of a solar heating system with sodium thiosulfate pentahydrate as PCM. It was obtained an increase in the produced hot water mass and total heat accumulated approximately 2.593.45 times of the conventional solar waterheating system. (Cabeza et al., 2006) constructed an experimental solar pilot plant to test the PCM behavior in real conditions. It was obtained a discharge temperature stabilization near to $54 \mathrm{IC}$ for a period of time between 10 and 12 h. (Mettawee and Assassa, 2006) performed parametric studies of different operating conditions, concluding that as the material melts, the heat transfer by convection increases the speed of the accumulation process. (Koca et al., 2008) performed an analysis of energy and exergy a latent heat storage system with phase change material (PCM) for a flat-plate solar collector. The obtained experimental data showed that exergy efficiencies of latent heat storage systems with PCM are very low. However, the area of collector surface was smaller than that of the PCM surface area. As a result of this, the cost of the latent heat storage system was high and outlet temperature obtained was low. (Bouadila et al., 2014) have developed an experimental study on a solar flat plate water heater with an accumulation of thermal energy in the collector using a PCM. Experimental measurements ascertain that the outlet temperature was not affected by the severe global solar radiation fluctuations. The solar collector remains a uniform useful heat around $400 \mathrm{~W}$ during $5 \mathrm{~h}$ after sunset. (Serale et al., 2014) present an approach to increase the performance of flat collectors based on the exploitation of the latent heat of the heat carrier fluid. The aim of this paper is to analyze experimentally the performance of a lab-scale solar collector built with commercial features and a latent heat storage unit inside it.

\section{Method and materials}

It was designed and constructed a flat plate solar collector prototype with a cavity to place macro-encapsulated PCM under the absorber plate. A schematic representation of the prototype is shown in Fig. 1. Further details of the collector are presented in Fig. 2 and described in Table 1.

The PCM was microencapsulated in 4 rectangular steel containers of $4000 \times 4000 \times 30$ $\mathrm{mm}$. Each container was filled with $3.35 \mathrm{~kg}$ of semi refined paraffin wax with a nominal melting point between $58-60^{\circ} \mathrm{C}$.

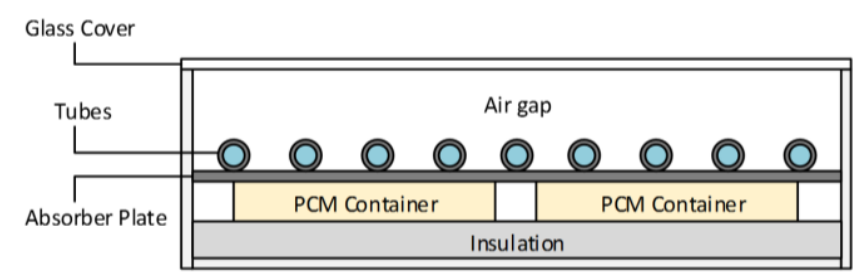

Figure 1. Schematic representation of the Solar Collector. 

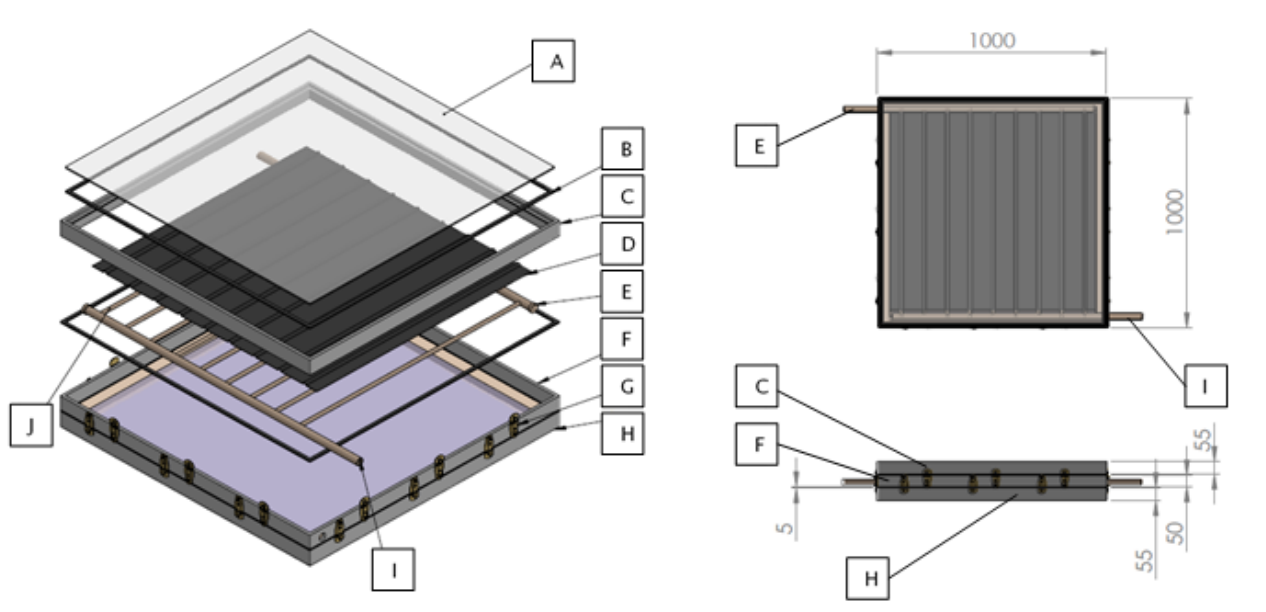

Figure. 1. Detailed view of the Solar Collector.

Table 1. Detailed component description of the collector

\begin{tabular}{ccc}
\hline Item & Description & Specifications \\
\hline A & Glass cover & Thickness: $4 \mathrm{~mm}$ \\
B & Gasket & -- \\
C & Air cavity case & Thickness: $4 \mathrm{~mm}$ Aluminum \\
D & Absorber plate & Thickness: $1 \mathrm{~mm}$ Copper \\
E & Inlet line pipe & Diameter: $25.4 \mathrm{~mm}$ Copper \\
F & Plate Case & Thickness: $4 \mathrm{~mm}$ Aluminum \\
G & Lockers & - \\
H & PCM Cavity & Internal polyurethane insolation \\
I & Outlet line & Diameter: $25.4 \mathrm{~mm}$ Copper \\
J & Absorber pipes & Diameter: $12.7 \mathrm{~mm}$ Copper Separation: $100 \mathrm{~mm}$ \\
\hline
\end{tabular}

The experimental set-up is shown in Error! Reference source not found.. The water was supplied by an Aqua Pak LOOP 3V32-9/1115 pump with a fixed volumetric flow rate of 0.2 $\mathrm{L} / \mathrm{min}$ and monitored by a rotameter Dwyer of $1.2 \mathrm{~L} / \mathrm{min}$. A weather station Davis Vantage Pro 2 Plus measured ambient temperature, wind speed, humidity and global solar radiation. Temperatures of the glass cover, confined air, absorber plate, water inlet, water outlet and PCM containers were measured with type-K thermocouples connected to a data acquisition unit Applent AT4532. 8 temperature channels were located on the absorber plate, 2 on the water inlet, 2 on the water outlet, 2 on the glass cover, 2 measured the confined air temperature, 4 on the top of the PCM containers and 4 at the bottom.

The experimental tests were carried out in 3 experimental campaigns with 20 days each one. The first campaign was performed in October 2016, the second in December 2016 and the third in February 2017. All at the test took place in Universidad del Norte campus, in Barranquilla Colombia $\left(11^{\circ} 1^{\prime} 12.17^{\prime \prime} \mathrm{N}, 74^{\circ} 51^{\prime} 5.44^{\prime \prime} \mathrm{O}\right)$. The test started at 7:00 AM monitoring all the variables every 5 minutes until the collector did not increase water temperature after sunset.

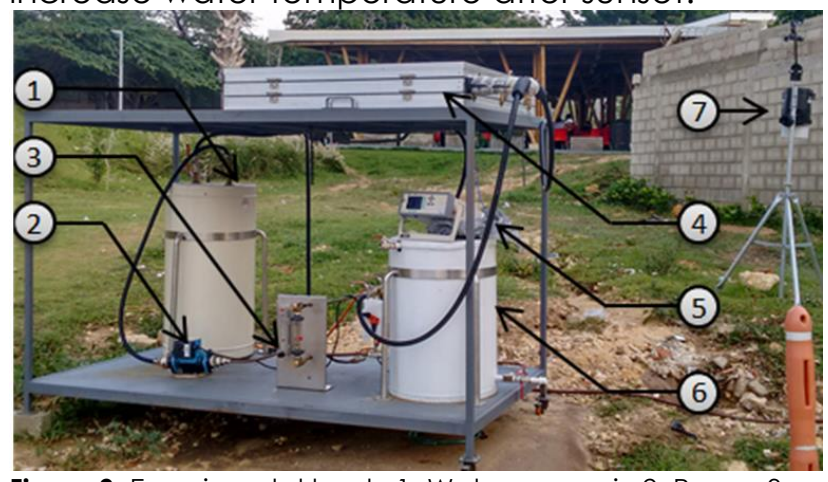

Figure 3. Experimental bank: 1. Water reservoir, 2. Pump, 3. Rotameter, 4. Solar collector, 5. Data acquisition unit, 6. Water reception tank, 7. Weather station.

\section{Results \& Discussion}

Results of accumulated radiation, useful heat and efficiency during the 60 days of experimentation are presented in Figure 2 and summarized in Table 2. The highest efficiency of the collector was obtained in tests carried out in December while the lowest value during tests executed in October. As can be observed in Table 2, while low efficiencies are found both in rainy season with low radiation and clear season 
with high radiation the highest efficiency values were obtained during medium radiation values.

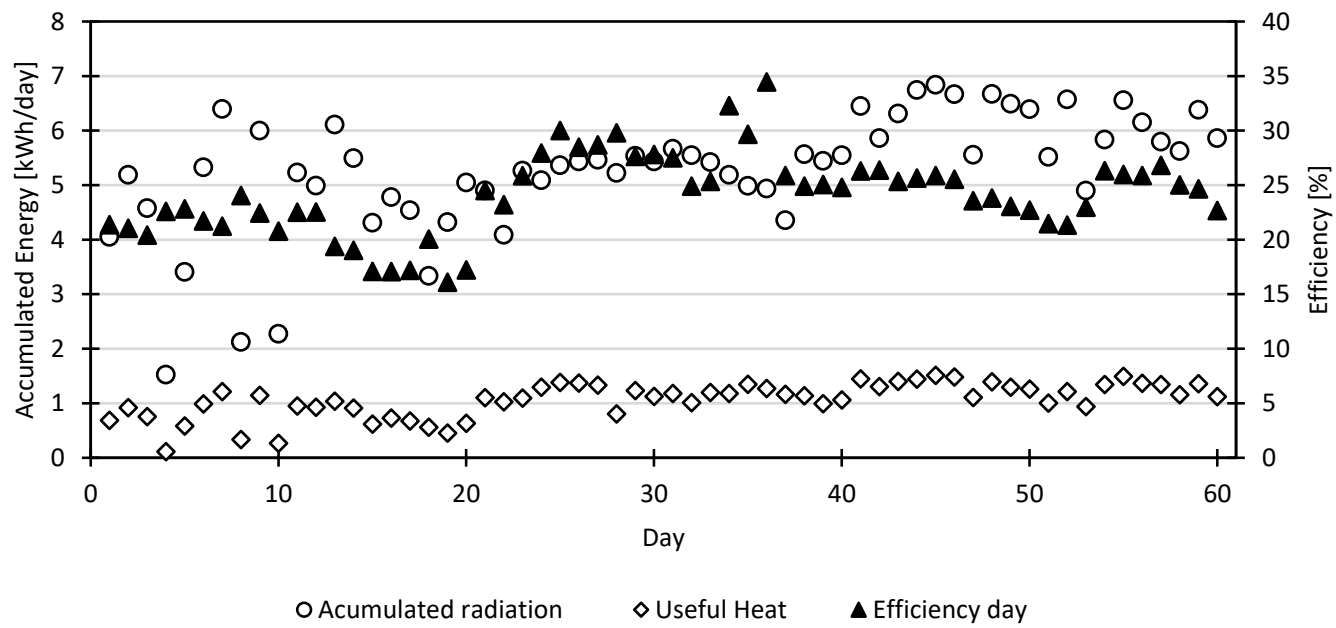

Figure 2. Experimental results by day.

Table 2. Results of the tests and weather conditions.

\begin{tabular}{cccccc}
\hline Exp. Campaign & $\begin{array}{c}\text { Days in } \\
\text { Figure X }\end{array}$ & Weather & $\begin{array}{c}\text { Average Acc.rad } \\
{[\mathrm{kWh} / \text { day }]}\end{array}$ & $\begin{array}{c}\text { Rad. Std. dev } \\
\text { [kWh/day] }\end{array}$ & $\begin{array}{c}\text { Average } \\
\text { Efficiency [\%] }\end{array}$ \\
\hline Oct & $01-20$ & Rainy & 4.45 & 1.33 & 20.34 \\
Dec & $21-40$ & Scattered & 5.22 & 0.41 & 27.44 \\
Feb & $41-60$ & Clear & 6.16 & 0.51 & 24.57 \\
\hline Total & & - & 5.27 & 1.10 & 24.11 \\
\hline
\end{tabular}

The following graphs present the behavior of the collector on March 12, 2017. Figure 3 and Figure 4 shows respectively the solar radiation and wind speed measured by the weather station. This day has a high incidence of solar radiation with an accumulated radiation of $5.27 \mathrm{kWh}$. Figure 5

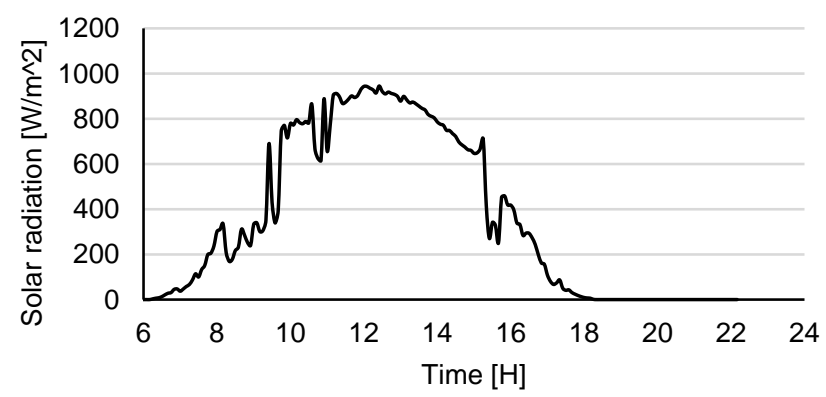

Figure 3. Solar radiation shows that the outlet temperature did not decrease too much during the cloudiness events of 11:00 and 15:00 which shows that the thermal energy storage system provides stability to the water supply.

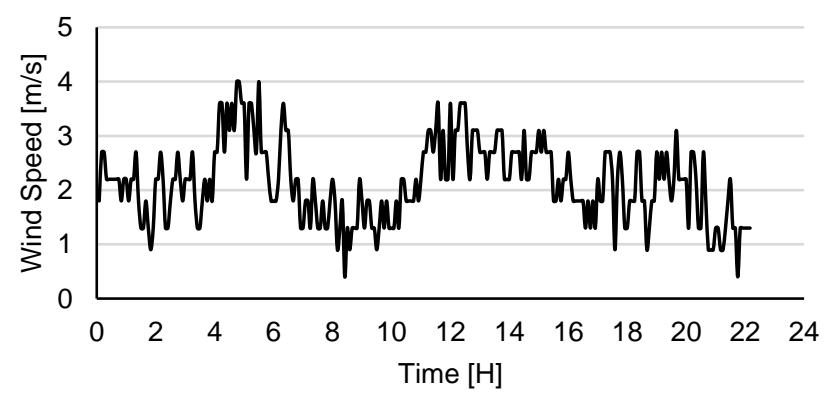

Figure 4. Wind speed 


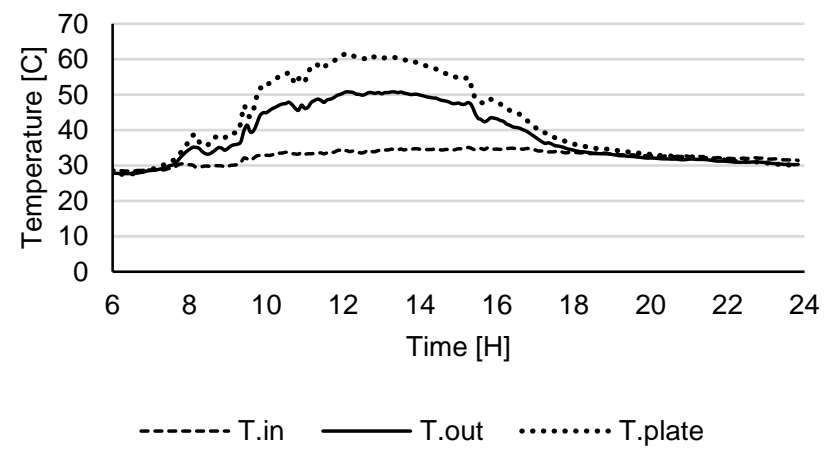

Figure 5. Temperatures of absorber plate, water inlet, and water outlet

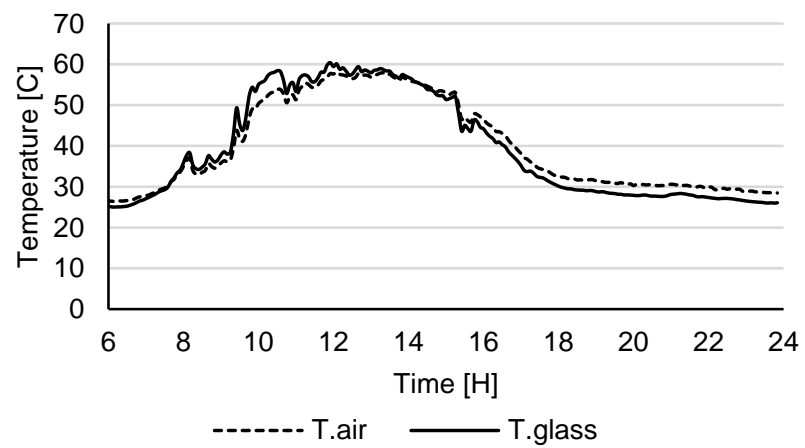

Figure 7. Temperature of air gap and glass cover

It can be observed in Figure 6 that the PCM containers store heat energy by sensible heat until 14:00, from where the temperature at container's top (T.PCMU) remains at $60^{\circ} \mathrm{C}$ until 16:00, indicating storage by latent heat. However, it should be noted in Figure 5 that the temperature of the absorber plate reaches the melting point of the PCM only for 2 hours, in many experimental tests the phase change temperature is never reached. This gives a short time to the PCM to accumulate energy by latent heat resulting in a PCM discharging process at a non-constant temperature. On the other hand, it can be seen in Figure 6 an asymmetric charge/discharge process. Despite the proper charging process during the morning the storage system was unable to provide thermal energy to the working fluid after 18:00 as can be seen in Figure 8 This may be due to an excess of PCM in the solar collector. In fact, Figure 6 shows that, although the upper part of the PCM reaches the phase change temperature, the lower part never reaches it and even its maximum temperature is reached about 2 hours later. Therefore, it can be inferred that during the night the molten PCM transfers heat to the solid PCM layers instead of the working fluid.

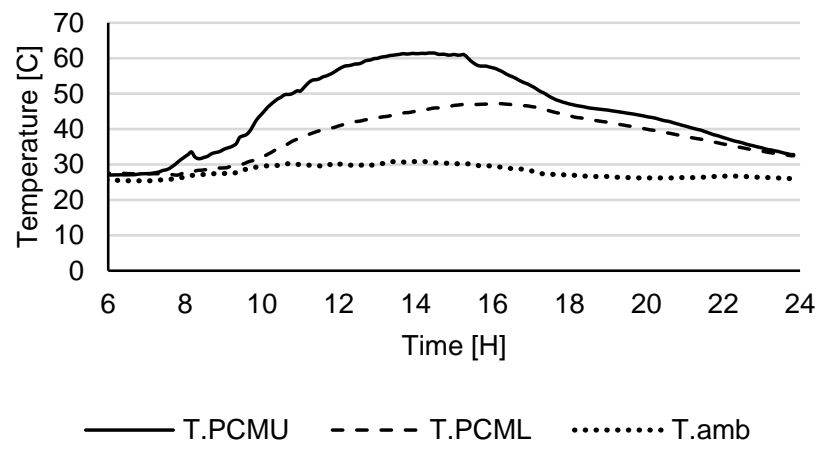

Figure 6. PCM Temperature and ambient temperature

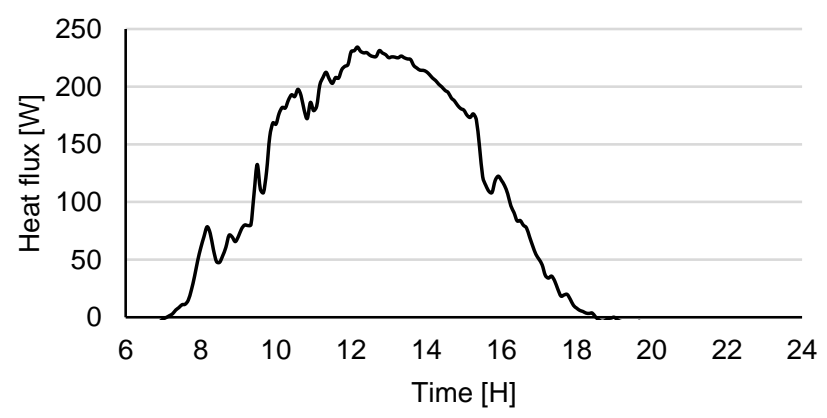

Figure 8. Useful Heat.

\section{Conclusions}

In this paper, an experimental analysis was carried out to evaluate the performance of a flat plate solar collector with integrated microencapsulated PCM as latent heat storage system. The highest efficiency of the prototype was obtained at accumulated radiation of 5.22 $\mathrm{kWh}$ /day. Values above or below this amount of radiation resulted in lower efficiency values. Asymmetric PCM charge/discharge process was observed. Therefore, reduce the PCM mass is recommended to avoid upper layers discharge thermal energy to lower layers instead of the absorber plate. It was obtained that the PCM modules provided stability to the outlet temperature against strong fluctuations in solar radiation. However, it was unable to supply thermal energy to the working fluid during the night. The short time the absorber plate reached the melting point of the PCM may be a cause of this. Thus, experimental analysis and simulation with PCM with lower phase change temperature is recommended.

\section{Acknowledgments}

This investigation has been partially funded by the Colombian Administrative Department of Science, Technology, and InnovationCOLCIENCIAS, through the program "es Tiempo 
de Volver". Authors wish to express their acknowledgments to COLCIENCIAS and its excellent program.

\section{Acknowledgement}

This research did not receive any specific grant from funding agencies in the public, commercial, or not-for-profit sectors.

\section{References}

Abhat, A. (1983). Low-temperature latent heat thermal energy storage: Heat storage materials. Sol. Energy, 30, 313-332. doi:10.1016/0038-092X(83)90186-X

Bouadila, S., Fteïti, M., Oueslati, M.M., Guizani, A., Farhat, A. (2014). Enhancement of latent heat storage in a rectangular cavity: a Solar water heater case study. Energy Convers. Manag. 78, 904-912. doi:10.1016/j.enconman.2013.07.094

Cabeza, L.F., Ibáñez, M., Solé, C., Roca, J., Nogués, M.( 2006). Experimentation with a water tank including a PCM module. Solar Energy Materials and Solar Cells,90 (9), 1273-1282. doi:10.1016/j.solmat.2005.08.002

Canbazoglu, S., Sahinaslan, A., Ekmekyapar, A., Aksoya, Y., Akarsu, F. (2005). Enhancement of solar thermal energy storage performance using sodium thiosulfate pentahydrate of a conventional solar water-heating system. Energy Build, 37, 235242. doi:10.1016/j.enbuild.2004.06.016

Chandel, S.S., Agarwal, T. (2017). Review of current state of research on energy storage, toxicity, health hazards and commercialization of phase changing materials. Renew. Sustain. Energy Rev,67, 581-596. doi:10.1016/j.rser.2016.09.070

Farid, M.M., Khudhair, A.M., Razack, S.A.K., AlHallaj, S. (2004). A review on phase change energy storage: materials and applications. Energy Convers. Manag. 45, 1597-1615. doi:10.1016/j.enconman.2003.09.015

Kenisarin, M., Mahkamov, K. (2007). Solar energy storage using phase change materials. Renew. Sustain. Energy Rev, 11, 1913-1965. doi:10.1016/j.rser.2006.05.005

Koca, A., Oztop, H.F., Koyun, T., Varol, Y. (2008). Energy and exergy analysis of a latent heat storage system with phase change material for a solar collector. Renew. Energy, 33. doi:10.1016/j.renene.2007.03.012

Kürklü, A., Özmerzi, A., Bilgin, S. (2002). Thermal performance of water-phase change material solar collector. Renew. Energy, 26, 391-399. doi:10.1016/S0960-1481 (01)00130-6

Mehling, H., Hippeli, S., Hiebler, S., Cabeza, L.F. (2003). PCM-module to improve hot water heat stores with stratification. Renew. Energy, 28, 699-711. doi:10.1016/S09601481 (02)00108-8

Mettawee, E.B.S., Assassa, G.M.R.(2006). Experimental study of a compact PCM solar collector. Energy ,31, 2622-2632. doi:10.1016/j.energy.2005.11.019

Nkwetta, D.N., Haghighat, F., 2014. Thermal energy storage with phase change material - A state-of-the art review. Sustain. Cities Soc. 10, 87-100. doi:10.1016/j.scs.2013.05.007

Pandey, K.M., Chaurasiya, R. (2017). A review on analysis and development of solar flat plate collector. Renew. Sustain. Energy Rev, 67, 641-650. doi:10.1016/j.rser.2016.09.078

Serale, G., Baronetto, S., Goia, F., Perino, M. (2014). Characterization and energy performance of a slurry PCM-based solar thermal collector: A numerical analysis, in: Energy Procedia, $48 \quad .223-232$. doi:10.1016/j.egypro.2014.02.027

Sharma, A., Tyagi, V.V., Chen, C.R., Buddhi, D. (2009). Review on thermal energy storage with phase change materials and applications. Renew. Sustain. Energy Rev, 13, 318-345. doi:10.1016/j.rser.2007.10.005

Zalba, B., Marín, J.M., Cabeza, L.F., Mehling, H. (2003). Review on thermal energy storage with phase change: Materials, heat transfer analysis and applications. Appl. Therm. Eng, 23, 251-283. doi:10.1016/S1359$4311(02) 00192-8$ 